(C) The Author(s), 2021. Published by Cambridge University Press on behalf of the Arizona Board of Regents on behalf of the University of Arizona. This is an Open Access article, distributed under the terms of the Creative Commons Attribution licence (http://creativecommons.org/licenses/by/4.0/), which permits unrestricted re-use, distribution, and reproduction in any medium, provided the original work is properly cited.

\title{
THE BEGINNING OF THE IRON AGE AT ARSLANTEPE: A ${ }^{14} \mathrm{C}$ PERSPECTIVE
}

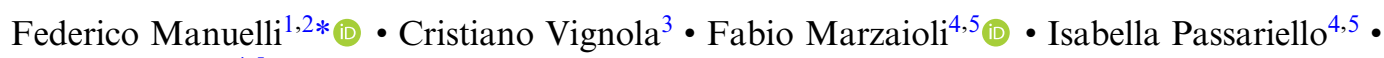
Filippo Terrasi ${ }^{4,5}$ (1)

\author{
${ }^{1}$ National Research Council of Italy (CNR), Institute of Heritage Science (ISPC), P.O. Box 10, 00015 Monterotondo \\ Scalo, Rome, Italy \\ ${ }^{2}$ Freie Universität Berlin, Institut für Altorientalistik, Fabeckstraße 23-25, D-14195 Berlin, Germany \\ ${ }^{3}$ Sapienza University of Rome, Department of Environmental Biology, Piazzale Aldo Moro 5, 00185 Rome, Italy \\ ${ }^{4}$ University of Campania “Luigi Vanvitelli", Department of Mathematics and Physics, Viale Lincoln, 5, 81100 Caserta, \\ Italy
}

${ }^{5}$ CIRCE Lab-Innova S.C.aR.L (Centre for Isotopic Research on Cultural and Environmental heritage), Viale Carlo III 147, 80120 San Nicola la Strada (CE), Italy

\begin{abstract}
The Iron Age chronology at Arslantepe is the result of the interpretation of Luwian hieroglyphic inscriptions and archaeological data coming from the site and its surrounding region. A new round of investigations of the Iron Age levels has been conducted at the site over the last 10 years. Preliminary results allowed the combination of the archaeological sequence with the historical events that extended from the collapse of the Late Bronze Age empires to the formation and development of the new Iron Age kingdoms. The integration into this picture of a new set of radiocarbon $\left({ }^{14} \mathrm{C}\right)$ dates is aimed at establishing a more solid local chronology. High precision ${ }^{14} \mathrm{C}$ dating by accelerator mass spectrometry (AMS) and its correlation with archaeobotanical analysis and stratigraphic data are presented here with the purpose of improving our knowledge of the site's history and to build a reliable absolute chronology of the Iron Age. The results show that the earliest level of the sequence dates to ca. the mid-13th century BC, implying that the site started developing a new set of relationships with the Levant already before the breakdown of the Hittite empire, entailing important historical implications for the Syro-Anatolian region at the end of the 2nd millennium BC.
\end{abstract}

KEYWORDS: Anatolia, Bayesian analysis, ceramics, Iron Age, radiocarbon AMS dating.

\section{INTRODUCTION AND BACKGROUND}

Arslantepe is located in the fertile Malatya plain, in southeastern Turkey a few kilometers west of the Euphrates River (Figure 1). The site shows an uninterrupted occupation sequence covering the whole 2 nd and through the first part of the 1st millennium $\mathrm{BC}$. The beginning of the Iron Age at Arslantepe is marked by archaeological and historical continuity with the previous Late Bronze Age phases, in a period that, on the contrary, has been labelled for a long time as a "Dark Age" (Frangipane and Liverani 2013). The 12th century BC in Anatolia is marked by the dissolution of the Hittite empire and the subsequent development of a new set of independent regional entities, called the "Neo-Hittite" kingdoms (Bryce 2012). The formation and relationships of these polities have been widely debated by scholars. Recently, the synergy between archaeological, textual and scientific data has allowed comprehensive understanding of their chronological development, as well as their integration into the wider set of events that changed the Eastern Mediterranean world at the end of the 2nd millennium BC (Knapp and Manning 2016).

The Iron Age chronology of Arslantepe has been discussed from many perspectives in recent decades. Nonetheless, an overall reconstruction that takes into consideration archaeological and textual sources together with a reliable range of radiometric measurements has never been achieved. The first explorations at the site, carried out by a French expedition during

\footnotetext{
*Corresponding author. Email: federico.manuelli@enr.it
} 


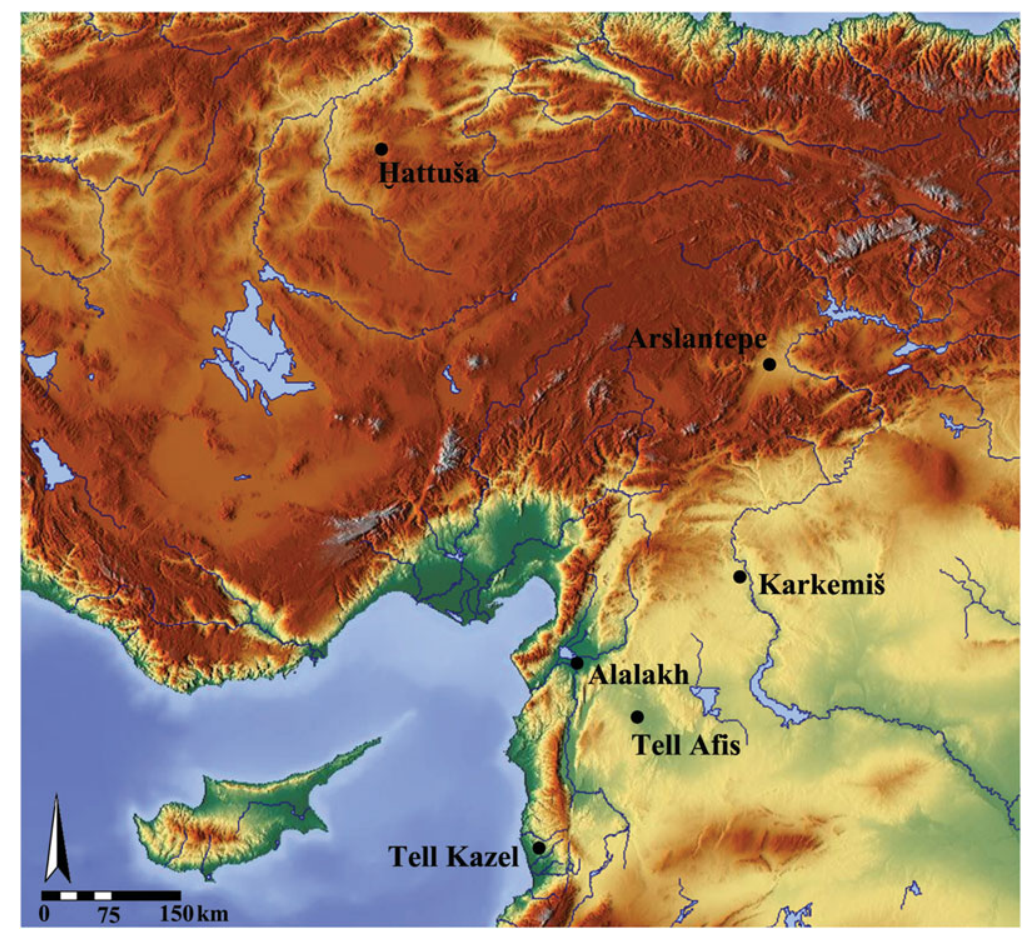

Figure 1 Map of the Syro-Anatolian region with the sites mentioned in the text (map courtesy of Maps for Free, compiled by the authors).

the 1930s, brought to light an impressive set of sculptured stone reliefs (Delaporte 1940). These artworks, together with some rock monuments distributed in the western portion of the Malatya plain, bear Luwian hieroglyphic inscriptions that undoubtedly date paleographically and philologically to the 12th and 11th century BC (Hawkins 2000: 282329; Dinçol et al. 2014). These texts attest to the existence of an important polity in Iron Age I named Malizi (referring to both the city and its region) with its capital at Arslantepe and its domain stretching along the valleys to the west. Analysis of the inscriptions has also allowed synchronization with the dynasties ruling at nearby Karkemiš (also referring to both the city and its polity), an important Hittite vice-regal seat that inherited the power of the capital-city Hattuša after its decay (Hawkins and Weeden 2016).

Archaeological investigations have been able to support this historical scenario. The Italian Archaeological Expedition in Eastern Anatolian (MAIAO) from Sapienza University of Rome has excavated at Arslantepe since 1961 (Frangipane 2019). Despite the fact that the investigations into the Iron Age levels have been conducted intermittently at the site, they were the focus of the first round of excavations performed by the Italian expedition. They allowed the unearthing of a long and continuous sequence that covers the whole Iron Age as well as the remains of a monumental Late Bronze Age gate-system and associated fortification wall (Pecorella 1975). The ${ }^{14} \mathrm{C}$ analysis of two charcoal samples collected from the destruction level of the Late Bronze Age gateway was carried out in 1966 (R-214 and R-214 $\beta$, Alessio et al. 1966). Measurements were obtained by using proportional gascounters with $\mathrm{CO}_{2}$ at 3 atm and by pretreating different amounts of charred material with 


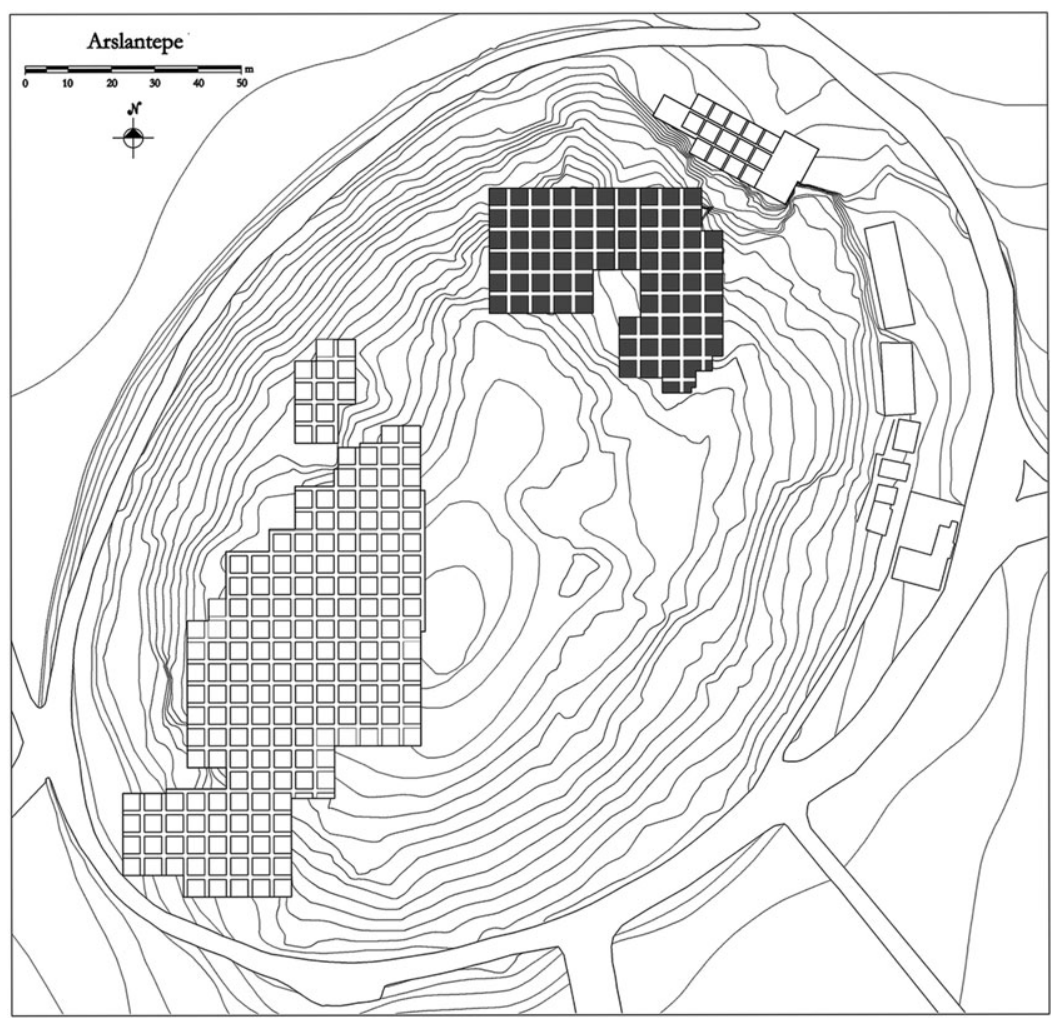

Figure 2 Topographic map of Arslantepe. Gray indicates the Iron Age areas investigated by the Italian expedition from 2008 to 2019 (CMAIAO).

an acid-base-acid (ABA) protocol (Alessio et al. 1964). The samples respectively dated this architectural level to $2835 \pm 70$ or $1207-837$ cal BC $(2 \sigma)$ and to $2795 \pm 60$ or $1111-824$ cal BC $(2 \sigma)$ (see Manuelli 2013: 347-353). Associated material shows strong affinities with the Hittite imperial repertoire of the 14th and 13th century BC from central Anatolian sites (Pecorella 1975: 31-33). Synchronization of these pieces of information suggested a dating for the destruction of the gate-system in the final Late Bronze Age, i.e., to the end of the 13th century BC (Manuelli 2013: 399-409).

Following a long interruption, investigations on the Late Bronze and Iron Age levels at Arslantepe restarted in 2008 (Figures 2 and 3). A new targeted project began with the aim of providing answers to specific unresolved questions about the development of the site during the 2nd and 1st millennia BC (Liverani 2012). An uninterrupted sequence of monumental structures, covering the entire Iron Age occupation at the site for a period that approximatively spans the 12 th to the 7 th century $\mathrm{BC}$ has been brought to light (Manuelli 2019: 163-168; Frangipane et al. 2019: 27-30). The Iron Age I (Arslantepe Period IIIA) and the following Iron Age II (Arslantepe Period IIIB) have been dated, based on a good amount of diagnostic material discovered either in situ or in sealed and well-preserved contexts, to the 12th and 11th centuries and to the 10th and 9th century BC respectively (Manuelli 2018; Manuelli 2020: 113-118). 


\begin{tabular}{|c|c|c|}
\hline PHASES & MAIN STRUCTURES / ACTIVITIES & RELATED EVENTS \\
\hline \multirow[b]{2}{*}{$\begin{array}{l}\text { ARSLANTEPE } \\
\text { IIIB }\end{array}$} & K1572 / K1575 / K1577 / K1859 / K1857 / K1865 & Pits dug on the final collapse of the fortification wall \\
\hline & $\begin{array}{c}\text { Layer } 8 \\
\text { K1574 / K1648 / K1650/K1860/K1861 / K1863 }\end{array}$ & $\begin{array}{l}\text { Final collapse of the fortification wall } \\
\text { Large silos, pits, and ephemeral structures }\end{array}$ \\
\hline $\begin{array}{l}\text { ARSLANTEPE } \\
\text { IIIA. } 2\end{array}$ & $\begin{array}{c}\text { Layer } 9-8 \alpha \\
\mathrm{M} 159-\mathrm{A} 1278 / \mathrm{A} 1421 \\
\end{array}$ & $\begin{array}{l}\text { Fortification wall destruction } \\
\text { Fortification wall and related plastered floors }\end{array}$ \\
\hline \multirow{2}{*}{$\begin{array}{l}\text { ARSLANTEPE } \\
\text { IIIA.1 }\end{array}$} & $\begin{array}{l}\text { Layer } 14 \\
\text { Layer } 15\end{array}$ & $\begin{array}{l}\text { Fill layers above the structures } \\
\text { "Green-building" collapse }\end{array}$ \\
\hline & $\begin{array}{c}\mathrm{A} 1479-\mathrm{A} 1426 \\
\mathrm{~A} 1436\end{array}$ & $\begin{array}{l}\text { "Green-building" construction and use } \\
\text { Round tower }\end{array}$ \\
\hline $\begin{array}{l}\text { ARSLANTEPE } \\
\text { IV }\end{array}$ & A 1300 & $\begin{array}{l}\text { LBA destruction } \\
\text { LBA gate system construction and use }\end{array}$ \\
\hline
\end{tabular}

Figure 3 Arslantepe, the excavated sequence from the final Late Bronze Age to the Iron Age II levels.

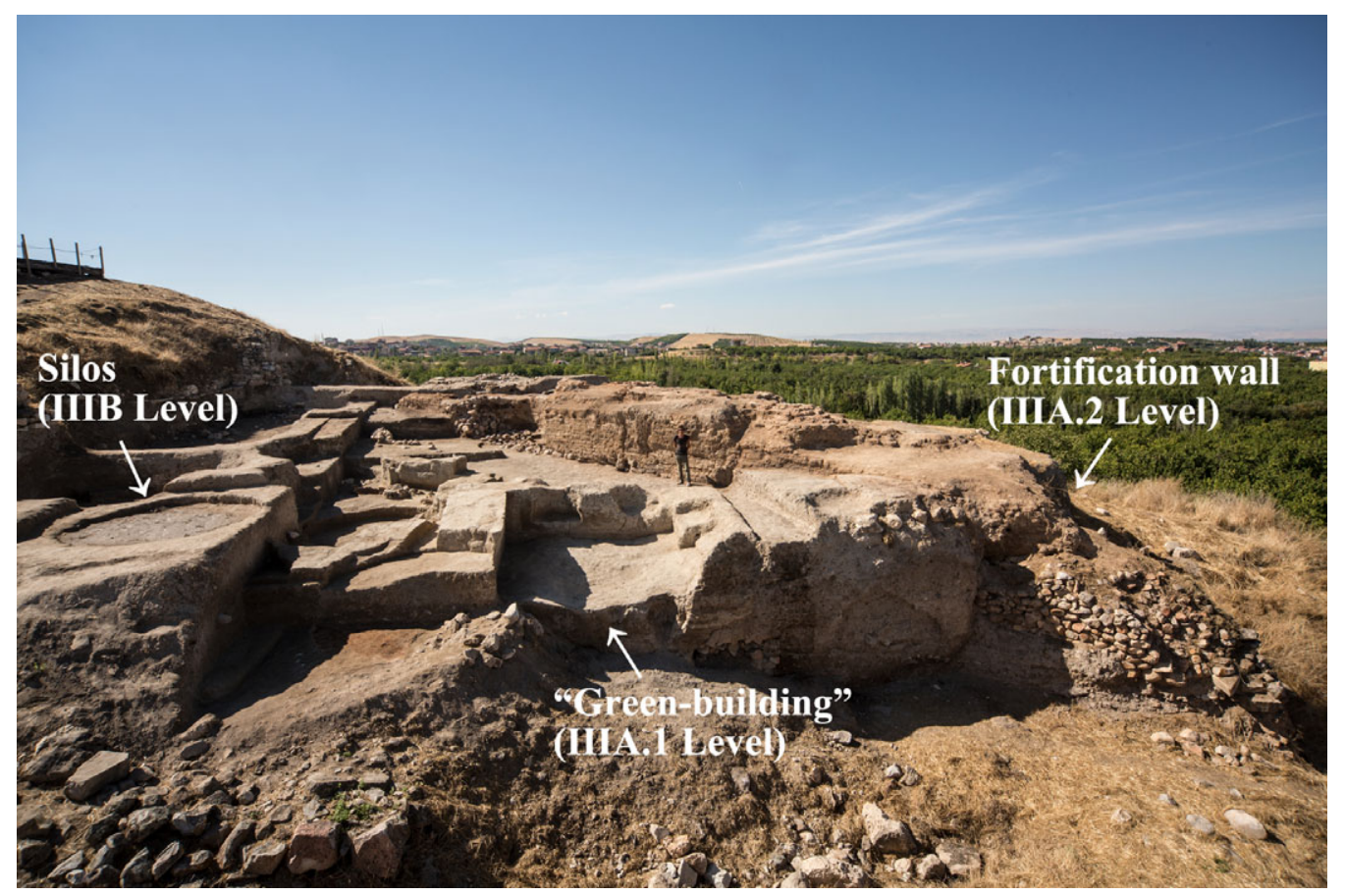

Figure 4 Arslantepe, the new excavated Iron Age monumental sequence (photo: R. Ceccacci, CMAIAO).

Three main architectural levels have been identified (Figure 4). The earliest Iron Age I level (Arslantepe IIIA.1) directly overlays the final destruction of the Hittite imperial gate-system (Arslantepe IV), marking the existence of an unbroken sequence of construction that starts from the final Late Bronze Age and does not show any stratigraphic or architectural hiatus. Two large rooms, whose thick walls were made of green colored mudbricks have been unearthed (Figure 5). Although there is no specific evidence at the moment that the two rooms were part of the same structure, it is also clear that they both belong to a 


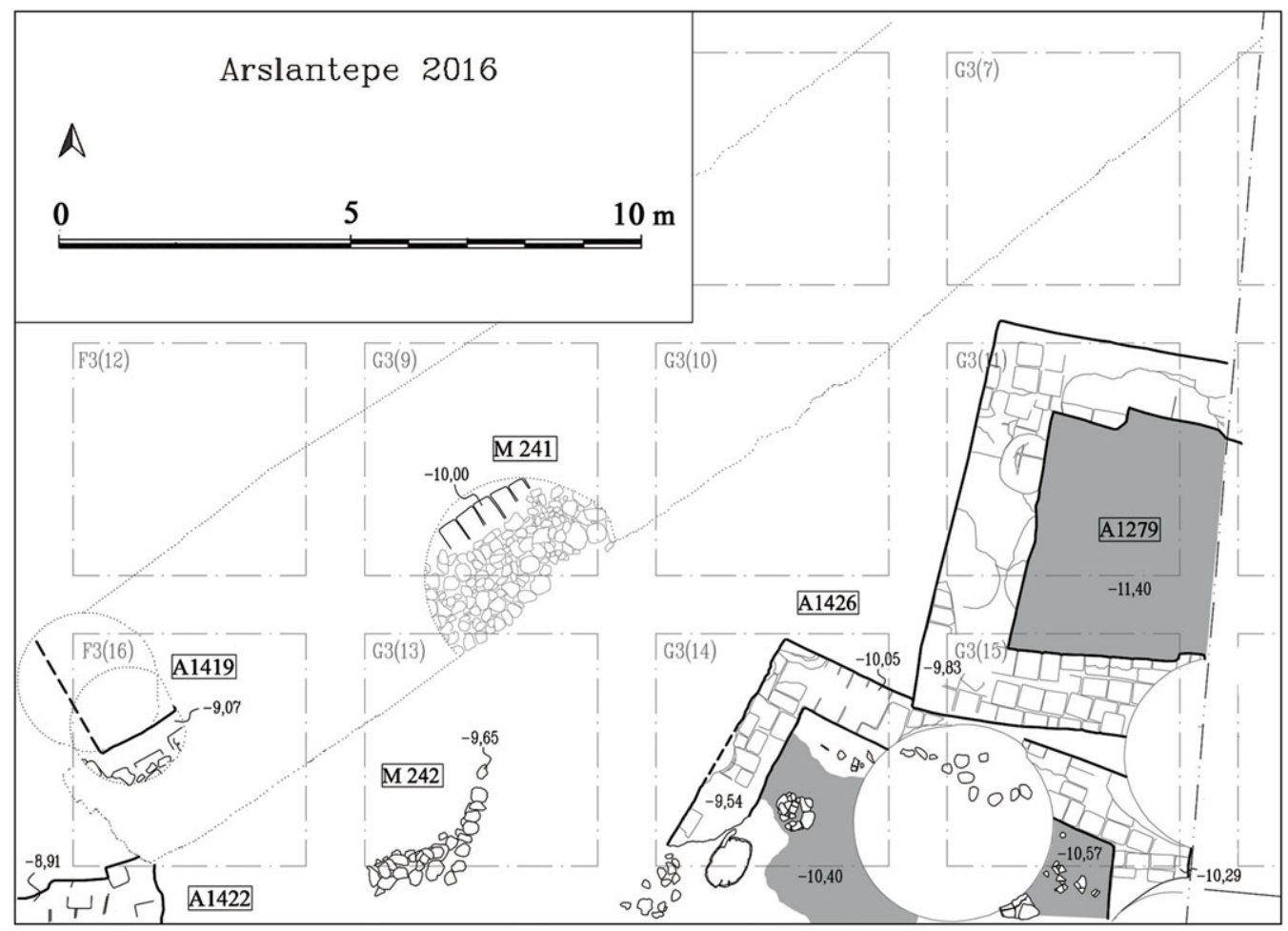

Figure 5 Arslantepe, the IIIA.1 "green-building" level. On the right the two rooms and on the left some only partially excavated structures belonging to this level (realized and elaborated by G. Liberotti, CMAIAO).

coherent and coeval architectural plan hence named the "green-building." Several phases of construction and use were identified. Interestingly no traces of a final destruction by fire have been recognized, and the rooms were intentionally filled probably following their collapse and abandonment (Frangipane et al. 2017: 84-89).

Traces of a fortification, lying underneath the rooms, have been discovered and only partially excavated. This consists at least of a round structure filled with mud and mud-brick pieces, probably representing a substructure or a tower. Despite the fact that the exact relationship between these structures is still not completely clear at the moment, the fact that the tower was built with green colored mudbricks and does not show any burnt traces allows us to assume the existence of one "green level" only, characterized by several phases of construction.

The two rooms have been found sealed underneath a thin mud-plastered floor associated with a massive fortification wall of mudbricks on a stone foundation (Figure 6). This later Iron Age I level (Arslantepe IIIA.2) was destroyed by a violent fire, as a thick layer of heavily burnt debris stemming from the wall collapse has been found over a large area. The excavation of the stone foundation revealed that the wall was built on several terraces with different elevations, following the ancient contours of the mound (Manuelli and Mori 2016: 216-222). Interestingly, one archaeomagnetic date obtained from the burnt mudbricks dated the wall fire to $1050 \pm 150 \mathrm{BC}$ (Ertepinar et al. 2012). 

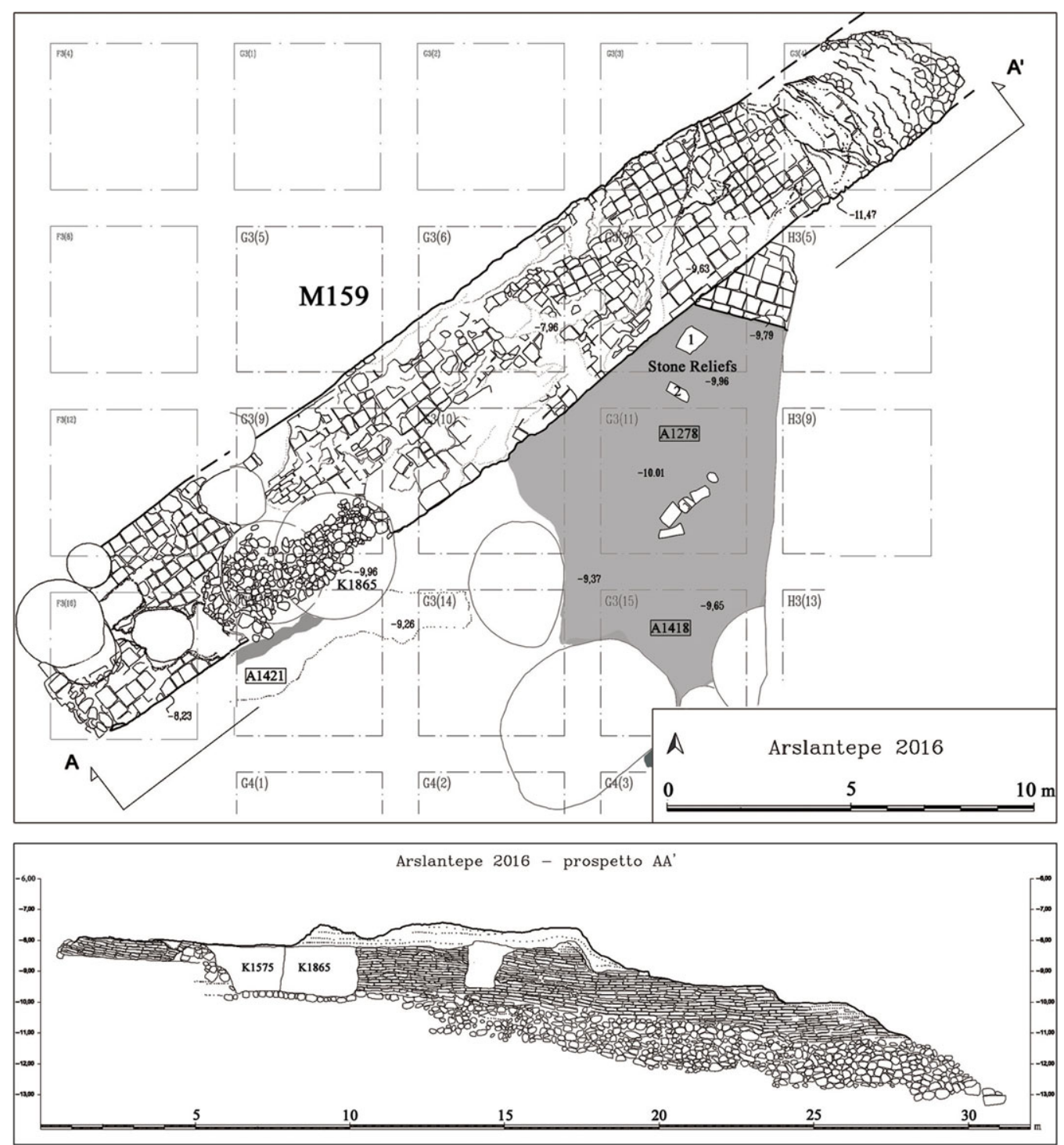

Figure 6 Arslantepe, the IIIA.2 fortification wall level: plan and profile (realized and elaborated by G. Liberotti, (CMAIAO).

The destruction of the fortification wall marks an interesting change in the occupation pattern of the northern part of the site (Figure 7). Despite a reuse of some of the earlier structures, the following Iron Age II levels (Arslantepe IIIB) are represented by a series of large silos and pits, indicating that the area was specifically devoted to storage activities (Manuelli 2020: 113-118). Some of the pits are certainly coeval with the silos but others cut through them, showing the existence of two different phases. It should be also noted that both silos and pits have been found filled with earth and debris, i.e., reused as dump. If the original use for storing activities is certain for the silos, considering the presence of internal partitions and installations as well as of chaff plaster, the original role of the pits is actually not always easy to determine. 


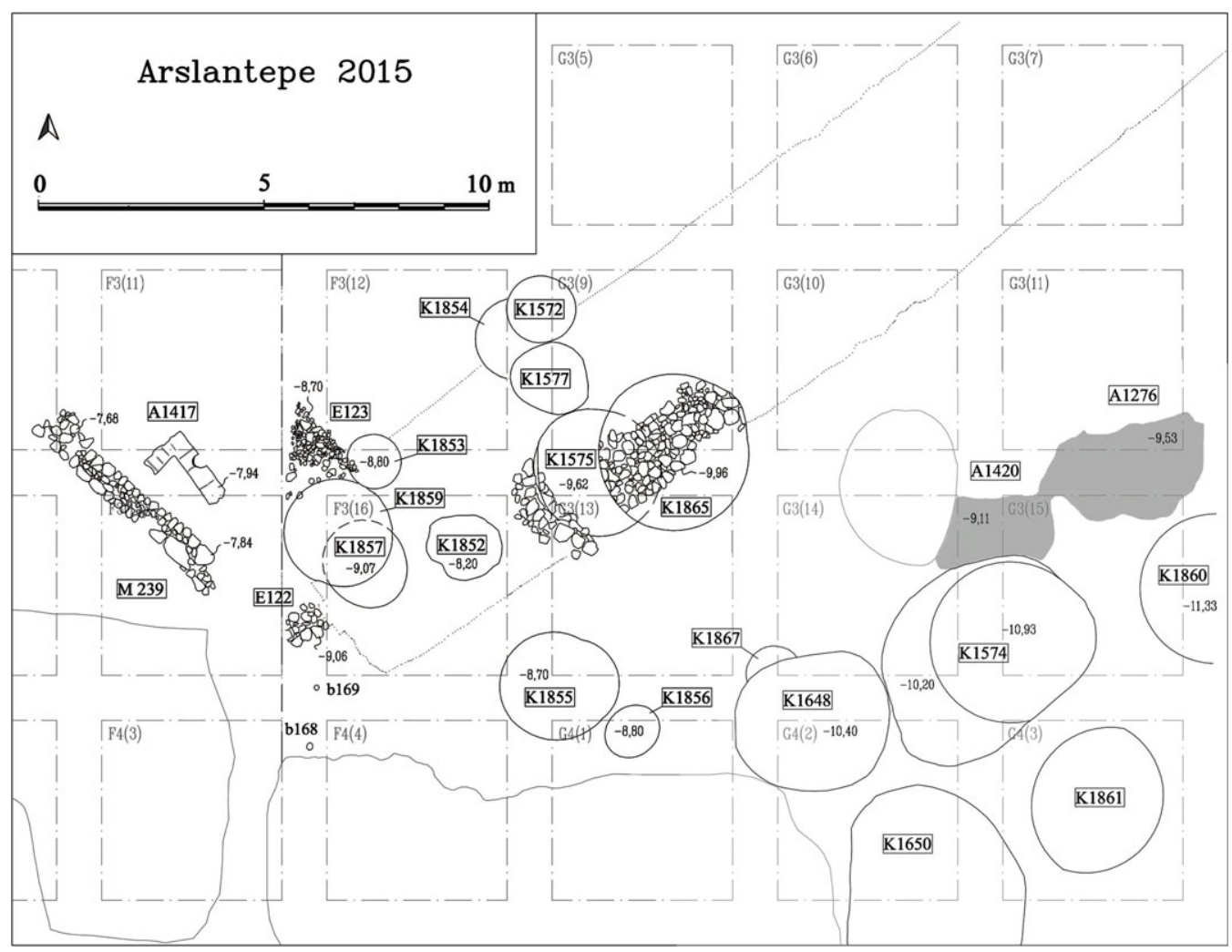

Figure 7 Arslantepe, the III.B silos and pits level (realized and elaborated by G. Liberotti, CMAIAO).

The examination of a well-contextualized collection of material coming from levels IIIA.1 and IIIA. 2 shows both aspects of continuity with previous traditions at the site, as well as the introduction of new cultural features. A set of new pottery shapes, e.g., trefoil jugs, handled jars, small squat body cooking-pots and neckless pithoi, as well as clay spoolshaped loom weights reflects remarkable connections with material dated from the end of the Late Bronze Age to the Iron Age I in northern Syria and the Levantine region (Manuelli 2018: 146-155). Unlike other southern sites that are closer to the coast, Aegean or Aegean-inspired pottery is completely missing in these levels at Arslantepe. Connections with the Levant increases during Period IIIB, as is especially shown by the slow introduction and following spread of red-slip ware (Manuelli 2019: 165-166).

In sum, the sequence of the beginning of the Iron Age at Arslantepe has been well established based on a wide set of reliable archaeological records and within a consistent historical framework. It is clear how the integration of new ${ }^{14} \mathrm{C}$ dates together with stratigraphic reconstruction is essential to better define the site's development as well as to create a ${ }^{14} \mathrm{C}$-based sequence that allows the establishment of a more solid local chronology. The chronological analysis is also essential for the wider and more consistent reconstruction of the history of the site, considering that the sequence of Arslantepe has been mostly built on a large set of ${ }^{14} \mathrm{C}$ dates assembled over several decades (Alessio et al. 1966, 1976, 1983; Calderoni et al. 1994; Di Nocera 2000; Vignola et al. 2019). Moreover, the recent correlation of high precision ${ }^{14} \mathrm{C}$ dating by accelerator mass spectrometry (AMS), 
archaeobotanical analysis, and stratigraphic data has demonstrated how the analytical methods can impact the construction of the archaeological chronologies (Vignola et al. 2019: fig. 4-5).

\section{MATERIALS AND METHODS}

The preservation of building levels at Arslantepe has already been shown to be suitable for dating the continuous sequence of occupation phases by a thorough selection of biological remains from undisturbed sealed contexts (i.e., Late Chalcolithic and Bronze Ages, Vignola et al. 2019). In order to assess the construction sequence of the Iron Age I and determine how long the "green-building" and the fortification wall were in use respectively, different samples were recovered during excavation. From the IIIA.1 level (Figure 5), two samples were collected among the collapsed mudbricks of the round tower $(27 / 2016,30 / 2016)$ and one sample was collected from inside a circular stone structure of room A1426 probably made to support a large vessel (142/2015). They represent the construction and primary use of the "green-building". Moreover, seven samples were taken from the following fill layers in the outer area that mark the end use of the IIIA.1 structures (48/2015, 18/2016, 19/2016, 20/2016, 22/2016, 26/2016, 323/2016). The IIIA.2 samples were all collected from various locations in the massive wall area (Figure 6). One sample was taken from the still standing mudbricks of the lower part of the wall (99/2015), probably relating to its construction phase. Another five samples were recovered from the burnt debris of the wall collapse that was stratigraphically separated (219/2010, 235/2010, 238/2010, 42/2015, 43/2015).

In order to assay when the occupation pattern changed and how long this site area was devoted to the storage during the Iron Age II, the IIIB samples were collected from the fill of silo K1574 (331/2009, 346/2009), and pit K1859 (137/2015) cutting the silo (Figure 7).

All samples consisted of charred wood material (charcoal); the identification was carried out at the Laboratory of Paleobotany and Palynology of the Sapienza University of Rome, Italy. In selecting charcoals for dating short-lived and fast-growing species were preferred, such as the rose family (Rosaceae) and poplar (Populus). Nonetheless, most of the charcoals were of deciduous oaks (deciduous Quercus) that are long-lived trees. In order to avoid the "old-wood" effect (Kim et al. 2019) and to obtain dates as close as possible to the occupational phases displayed by the archaeological evidence, we selected young branches or the last extant rings of heartwood or sapwood lacking any evidence of this boundary on the wood fragments. The aim was to date the growth period of the tree as close as possible to its use in the contexts: woods from IIIA.1 and IIIA.2 levels refer to timber remains, with the exception of the fragment from room A1426 that may have been part of some domestic installation. The IIIB charcoals are probably residual in dump layers of the silo/pit, even if their use in relation to these structures cannot be excluded (i.e., wooden roof or partitions).

From the samples, 15 were analyzed at CIRCE (Centre for Isotopic Research on the Cultural and Environmental heritage) lab of the University of Campania "Luigi Vanvitelli" in Caserta, Italy and the remaining 4 at CEDAD (CEnter for DAting and Diagnostics) lab of the University of Salento in Lecce, Italy (Table 1).

Taphonomic processes strongly impacted the preservation state of the samples and chemical pretreatment was required. Non-structural materials were removed by an Acid-Alkali-Acid (AAA) treatment (D'Elia et al. 2004; Passariello et al. 2007). At CIRCE lab, each sample was kept in hot-sealed teflon envelope in order to prevent the loss of charred material. 
Table 1 Radiocarbon dates and calibrated ages from the Iron Age levels of Arslantepe.

\begin{tabular}{|c|c|c|c|c|c|c|}
\hline Lab number & $\begin{array}{l}\text { Sample } \\
\text { code }\end{array}$ & $\begin{array}{l}\text { Arslantepe } \\
\text { period }\end{array}$ & Label context* & Plant species & $\begin{array}{l}\text { Conventional age } \\
\text { (BP) }\end{array}$ & Calendric age $(2 \sigma)$ \\
\hline DSH9100_CH & $20 / 2016$ & IIIA.1 & G3(7) $14 \mathrm{~h}$ & dec. Quercus & $3046 \pm 16$ & $\begin{array}{l}(50.0 \%) 1323-1257 \text { cal BC } \\
(41.2 \%) 1392-1336 \text { cal BC } \\
(4.2 \%) 1246-1228 \text { cal BC }\end{array}$ \\
\hline DSH9101_CH & $19 / 2016$ & IIIA.1 & G3(7) $14 \mathrm{~h}$ & Fraxinus sp. & $2970 \pm 16$ & $(95.4 \%) 1260-1123$ cal BC \\
\hline DSH9102_CH & $142 / 2015$ & IIIA.1 & G3(14) A1426 E1 & Ulmus sp. & $3003 \pm 17$ & $\begin{array}{l}(85.1 \%) 1299-1194 \text { cal BC } \\
(5.0 \%) 1375-1353 \text { cal BC } \\
(2.8 \%) 1144-1130 \text { cal BC } \\
(2.5 \%) 1175-1162 \text { cal BC }\end{array}$ \\
\hline DSH9103_CH & $238 / 2010$ & IIIA. 2 & G3(11) 9 & dec. Quercus & $2938 \pm 24$ & $(95.4 \%$ ) 1224-1048 cal BC \\
\hline DSH9104_CH & $42 / 2015$ & IIIA. 2 & F4(4) 8 a $\alpha$ & Populus sp. & $2942 \pm 18$ & $(95.4 \%)$ 1219-1055 cal BC \\
\hline DSH9105_CH & $26 / 2016$ & IIIA.1 & G3(10-11) $14 \mathrm{i}$ & dec. Quercus & $3021 \pm 19$ & $\begin{array}{l}(76.2 \%) 1311-1209 \text { cal BC } \\
(19.3 \%) 1384-1341 \text { cal BC }\end{array}$ \\
\hline DSH9106_CH & $18 / 2016$ & IIIA.1 & $\mathrm{G} 3(10-11) 14 \mathrm{f}$ & $\begin{array}{l}\text { Rosaceae } \\
\text { Maloideae }\end{array}$ & $3025 \pm 16$ & $\begin{array}{l}(74.2 \%) 1307-1217 \text { cal BC } \\
(21.2 \%) 1382-1343 \text { cal BC }\end{array}$ \\
\hline DSH9107_CH & $137 / 2015$ & IIIB & F3(16) K1859 2 d & dec. Quercus & $2891 \pm 19$ & $\begin{array}{l}(91.6 \%) 1128-1006 \text { cal BC } \\
(2.2 \%) 1191-1177 \text { cal BC } \\
(1.6 \%) 1158-1147 \text { cal BC }\end{array}$ \\
\hline DSH9110_CH & $27 / 2016$ & IIIA.1 & $\mathrm{G} 3(14) 15 \mathrm{~b}$ & dec. Quercus & $2981 \pm 16$ & $\begin{array}{l}(80.9 \%) 1265-1155 \text { cal BC } \\
(14.5 \%) 1149-1126 \text { cal BC }\end{array}$ \\
\hline DSH9191_CH & $99 / 2015$ & IIIA. 2 & G3(13) M159r & dec. Quercus & $3015 \pm 23$ & $\begin{array}{l}(76.6 \%) 1311-1196 \text { cal BC } \\
(16.1 \%) 1384-1341 \text { cal BC } \\
(1.5 \%) 1142-1132 \text { cal BC } \\
(1.3 \%) 1173-1163 \text { cal BC }\end{array}$ \\
\hline DSH9193_CH & $48 / 2015$ & IIIA.1 & F3(16) $11 \mathrm{~b}$ & dec. Quercus & $2981 \pm 20$ & $(95.4 \%) 1272-1123$ cal BC \\
\hline DSH9194_CH & $22 / 2016$ & IIIA.1 & G3(7) $14 \mathrm{i}$ & Ulmus sp. & $3010 \pm 27$ & $\begin{array}{l}(73.5 \%) 1312-1190 \text { cal BC } \\
(14.2 \%) 1384-1340 \text { cal BC } \\
(3.9 \%) 1180-1158 \text { cal BC } \\
(3.8 \%) 1146-1128 \text { cal BC }\end{array}$ \\
\hline
\end{tabular}




\begin{tabular}{|c|c|c|c|c|c|c|}
\hline Lab number & $\begin{array}{l}\text { Sample } \\
\text { code }\end{array}$ & $\begin{array}{l}\text { Arslantepe } \\
\text { period }\end{array}$ & Label context* & Plant species & $\begin{array}{l}\text { Conventional age } \\
\text { (BP) }\end{array}$ & Calendric age $(2 \sigma)$ \\
\hline DSH9222_CH & $43 / 2015$ & IIIA. 2 & F4(4) 8 a $\alpha$ & Populus sp. & $2879 \pm 19$ & $(95.4 \%)$ 1125-985 cal BC \\
\hline DSH9503_CH & $30 / 2016$ & IIIA.1 & $\mathrm{G} 3(10-14) 15 \mathrm{~b}$ & Populus sp. & $3012 \pm 16$ & $\begin{array}{l}(85.2 \%) 1304-1200 \text { cal BC } \\
(10.2 \%) 1379-1348 \text { cal BC }\end{array}$ \\
\hline LTL14917A & $331 / 2009$ & IIIB & G3(14) K1574 1 d & Populus sp. & $2774 \pm 40$ & $(95.4 \%) 1012-825 \mathrm{cal} \mathrm{BC}$ \\
\hline LTL14918A & $346 / 2009$ & IIIB & G3(14) K1574 $1 \mathrm{~b} \alpha$ & dec. Quercus & $2746 \pm 40$ & $(95.4 \%$ ) 986-811 cal BC \\
\hline LTL14919A & $235 / 2010$ & IIIA. 2 & $\mathrm{G} 3(11) 9 \mathrm{~b}$ & dec. Quercus & $2950 \pm 45$ & $\begin{array}{l}(95.0 \%) 1286-1012 \mathrm{cal} \mathrm{BC} \\
(0.5 \%) 1366-1360 \mathrm{cal} \mathrm{BC}\end{array}$ \\
\hline LTL14920A & $219 / 2010$ & IIIA. 2 & G3(11)(11-12) $9 \mathrm{~b}$ & dec. Quercus & $2927 \pm 45$ & $(95.4 \%)$ 1267-998 cal BC \\
\hline
\end{tabular}

*Square-Stratigraphic unit (layer/room/wall/pit)-Cut-Area. 
Nevertheless, sample 323/2016 completely dissolved during the alkaline step. As a result, only 18 of the originally 19 submitted samples were dated.

All ${ }^{14} \mathrm{C}$ dates were determined by AMS (Terrasi et al. 2008; Calcagnile et al. 2019). After the chemical pretreatment, the samples were graphitized according to lab procedures (D'Elia et al. 2004; Marzaioli et al. 2008). Radiocarbon ages were estimated according to Stuiver and Polach (1977) by applying the online isotope fractionation correction. The dates were calibrated using the IntCal 20 calibration curve using the OxCal 4.4 software (Bronk Ramsey and Lee 2013; Reimer et al. 2020).

To refine the chronological assessment the Bayesian chronological modeling was employed using the OxCal 4.4 software including outlier analysis (Bronk Ramsey 2009a, b; Bronk Ramsey and Lee 2013). Specifically, the Charcoal outlier model was applied in order to overcome the possibility of in-built age caused by a heartwood dating. The estimate of ca. 10-20 years of sapwood from Anatolian oak trees cannot be ruled out in the absence of such evidence (Griggs et al. 2009). The Arslantepe sequence for the Iron Age levels was constructed based on the observed stratigraphic relationships as reported in Figure 3.

\section{RESULTS}

The results of ${ }^{14} \mathrm{C}$ dating are reported in Table 1. All dates are coherent with the stratigraphic expectations. The IIIA.1 samples are on the average older than the IIIA.2 ones, and the IIIB samples are the youngest with the exception of the sample from pit K1859. Nonetheless, the date ranges within each archaeological phase do not overlap significantly.

The results of Bayesian modeling are presented in Table 2 and Figure 8 as calibrated date ranges at $95.4 \%$ probability. The model provides a potential calibrated age of $1320-1208$ cal BC for the beginning of the IIIA.1 phase. The transition between phases IIIA.1 and IIIA. 2 is modeled at $1256-1169$ cal $\mathrm{BC}$, while the end to the IIIB phase spans from 1001 to 776 cal BC.

All of the dates from the IIIA.1 sub-phases are clustered and the modeled date ranges overlap. This indicates that the "green-building" was certainly used during the 13th century BC. Specifically, the date of construction is estimated at 1264-1201 cal BC whereas the last (secondary) use is modeled at 1266-1203 cal BC. It is clear that the dates from the filling sub-phase refer to the intentional deposition of residual materials from the building itself, even if two separate processes might have been involved. In fact, a later deposition seems to be represented by the last two dates (Figure 8). Nevertheless, the floor associated with IIIA. 2 fortification wall definitively sealed the "green-building." The time-span occurring from the construction and use up to the abandonment of the "green-building" is estimated in 136 years at the latest ( $95.4 \%$ probability by applying the Interval query).

The results from the IIIA.2 samples suggest that the massive fortification wall was used from the end of the 13th century BC to the second half of the 11 th century BC. In accordance with the model, the wall construction is dated at $1228-1020 \mathrm{cal} \mathrm{BC}$. Looking in detail, the dates from the sub-phase of wall collapse are later than sample 99/2015 and occur over a long timeframe (spanning from 1216 to 1003 cal BC). Since the separation into two sub-phases is stratigraphically realistic despite the absence of direct evidence (Figure 3), we argue that two different processes were involved and that samples from wall debris might refer to later 
Table 2 Bayesian modeling of radiocarbon dates from the Iron Age levels of Arslantepe. The Charcoal outlier model of the OxCal 4.4 software was applied.

\begin{tabular}{|c|c|c|c|c|c|c|}
\hline \multirow[b]{2}{*}{ Sample } & \multicolumn{2}{|c|}{$\begin{array}{l}\text { Unmodeled } \\
\text { (BC/AD) }\end{array}$} & \multirow{2}{*}{$\frac{\text { Confidence }}{\%}$} & \multicolumn{2}{|c|}{$\begin{array}{l}\text { Modeled* } \\
\text { (BC/AD) }\end{array}$} & \multirow{2}{*}{$\frac{\text { Confidence }}{\%}$} \\
\hline & from & to & & from & to & \\
\hline \multicolumn{4}{|c|}{ Boundary Start Arslantepe IIIA.1 } & -1320 & -1208 & 95.4 \\
\hline \multicolumn{7}{|c|}{ Phase IIIA.1 } \\
\hline \multicolumn{7}{|c|}{ Sequence "green-building" } \\
\hline Boundary & "green- & ding" & & -1273 & -1206 & 95.4 \\
\hline \multicolumn{7}{|c|}{ Phase "green-building" } \\
\hline $27 / 2016$ & -1265 & -1126 & 95.4 & -1261 & -1203 & 95.4 \\
\hline $30 / 2016$ & -1379 & -1137 & 95.4 & -1263 & -1204 & 95.4 \\
\hline $142 / 2015$ & -1375 & -1130 & 95.4 & -1262 & -1204 & 95.4 \\
\hline \multicolumn{4}{|c|}{ Date estimate "green-building" construction/use } & -1264 & -1201 & 95.4 \\
\hline \multicolumn{4}{|c|}{ Boundary End "green-building" } & -1259 & -1195 & 95.4 \\
\hline \multicolumn{7}{|c|}{ Sequence filling activity } \\
\hline \multicolumn{4}{|c|}{ Boundary Start filling activity } & -1280 & -1207 & 95.4 \\
\hline \multicolumn{7}{|c|}{ Phase filling activity } \\
\hline 20/2016 & -1392 & -1228 & 95.4 & -1270 & -1205 & 95.4 \\
\hline $22 / 2016$ & -1384 & -1128 & 95.4 & -1266 & -1204 & 95.4 \\
\hline $26 / 2016$ & -1384 & -1208 & 95.4 & -1267 & -1205 & 95.4 \\
\hline $18 / 2016$ & -1382 & -1217 & 95.4 & -1267 & -1205 & 95.4 \\
\hline $48 / 2015$ & -1272 & -1123 & 95.4 & -1263 & -1205 & 95.4 \\
\hline $19 / 2016$ & -1260 & -1123 & 95.4 & -1262 & -1204 & 95.4 \\
\hline \multicolumn{4}{|c|}{ Date estimate "green-building" end use } & -1266 & -1203 & 95.4 \\
\hline \multicolumn{4}{|c|}{ Boundary End filling activity } & -1260 & -1197 & 95.4 \\
\hline \multicolumn{4}{|c|}{$\begin{array}{l}\text { Boundary between Arslantepe IIIA. } 1 \text { to } \\
\text { Arslantepe IIIA. } 2\end{array}$} & -1256 & -1169 & 95.4 \\
\hline \multicolumn{7}{|c|}{ Phase IIIA.2 } \\
\hline $99 / 2015$ & -1384 & -1131 & 95.4 & -1243 & -1115 & 95.4 \\
\hline \multicolumn{7}{|c|}{ Phase fortification wall collapse } \\
\hline $219 / 2010$ & -1266 & -990 & 95.4 & -1216 & -1026 & 95.4 \\
\hline $235 / 2010$ & -1367 & -1012 & 95.4 & -1225 & -1037 & 95.4 \\
\hline $238 / 2010$ & -1222 & -1022 & 95.4 & -1212 & -1047 & 95.4 \\
\hline $42 / 2015$ & -1218 & -1054 & 95.4 & -1211 & -1054 & 95.4 \\
\hline $43 / 2015$ & -1186 & -940 & 95.4 & -1185 & -1003 & 95.4 \\
\hline \multicolumn{4}{|c|}{ Date estimate wall construction } & -1228 & -1020 & 95.4 \\
\hline \multicolumn{7}{|c|}{ Phase IIIB } \\
\hline \multicolumn{7}{|l|}{ Phase silos } \\
\hline $331 / 2009$ & -1012 & -823 & 95.4 & -1042 & -854 & 95.4 \\
\hline $346 / 2009$ & -985 & -811 & 95.4 & -1037 & -832 & 95.4 \\
\hline $137 / 2015$ & -1191 & -1006 & 95.4 & -1096 & -962 & 95.4 \\
\hline \multicolumn{4}{|c|}{ Date estimate silos/pit activity } & -1089 & -851 & 95.4 \\
\hline \multicolumn{4}{|c|}{ Boundary End Arslantepe IIIB } & -1001 & -776 & 95.4 \\
\hline
\end{tabular}

building activities (restoration?). The possibility of in-built age for sample 43/2015, which is quite later than the others, cannot be ruled out; however, its intrusive nature is completely excluded by stratigraphical reasons (Figure 8). 


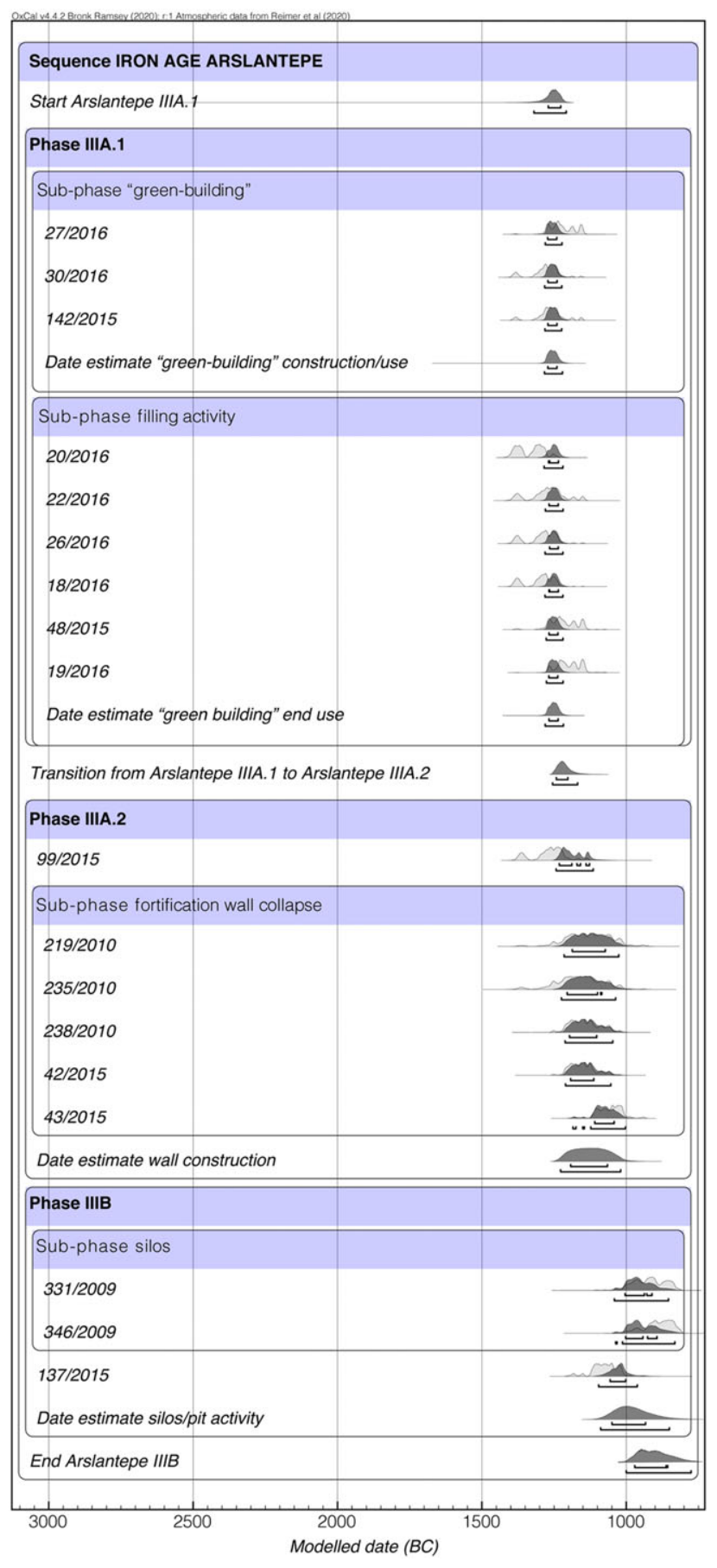

Figure 8 Multiplot of phases and sub-phases from the Iron Age levels of Arslantepe. Bayesian modeling with the Charcoal outlier model was applied (Indices: Amodel 89.1, Aoverall 87.5). 
Finally, the IIIB samples date the activities in the northern area of the site from the early 11 th to the mid-9th century BC. There is no chronological evidence that the burning of the imposing wall caused this site area to be abandoned: in fact, the estimated age for the use of the silos/pits is $1089-851$ cal BC even if the secondary depositional process must be taken into account. In this respect, the dates from the silos sub-phase are coherent with the stratigraphy (Figure 3) and fall in the same time frame after the fortification wall collapse (1042-854/1037-832 cal BC). They most likely refer to the IIIB use (primary or secondary) of the silo. On the contrary, the modeled date from pit K1859 is earlier (1096-962 cal BC) even if the pit cut the silo (Figure 3). For this reason, we consider the sample as residual (i.e., earlier) wood remains and not related to the context (Figure 8).

\section{DISCUSSION}

The results of the analysis here described have important implications for the chronology of the site and in general for the Syro-Anatolian world during the last centuries of the 2 nd millennium BC. Despite the fact that this is not the place to discuss the topic in detail, some archaeological and historical considerations are necessary.

It should be first of all noted that the results of the ${ }^{14} \mathrm{C}$ analysis proposed here provide dating that is slightly higher than expected, when considering the contexts of the samples even with a sapwood estimation. At the same time, the material coming from the examined contexts are not incompatible with the higher-than-expected dating.

The most interesting and at the same time controversial aspect of the analysis rises from the fact that what has been so far considered the earliest Iron Age level at Arslantepe (IIIA.1) actually represents, according to ${ }^{14} \mathrm{C}$ dating, the end of the Late Bronze Age. The chronology of Anatolia during the 2 nd millennium $\mathrm{BC}$ has been constructed on complex interpretations and correlations of written Hittite sources and archaeological data (Genz and Mielke 2011: 14-17). Geochemistry, and especially the radiocarbon application, have been integrated into this framework over a number of years, allowing improvement in the quality and precision of our knowledge about the history of the Hittite capital-city Hattuša and other sites (Schoop and Seeher 2006; Seeher 2018: 149-150). The end of the Hittite civilization and the following dawn of the Iron Age era have been the focus of many discussions amongst scholars (de Martino 2018). The unique blend of negative political, social, ideological, economic, demographic, and climatic issues is seen nowadays as the combined stress factor that induced the abrupt collapse of the empire (Schachner 2020: 392-393). In any case, the final abandonment and following destruction of Hattuša is firmly fixed at the very beginning of the 12 th century $\mathrm{BC}$, as also confirmed by correlated external sources (Knapp and Manning 2016: 126-127).

The establishment of the 2nd millennium BC chronology at Arslantepe cannot leave aside these premises. The end of the Late Bronze Age at the site has been always associated with the destruction of the so-called Hittite imperial gate. In light of the already mentioned ${ }^{14} \mathrm{C}$ samples analyzed in 1966, this correlation has been mostly based on the fact that this is the last architectural level at the site that contains proper Hittite central Anatolian material (Manuelli 2013: 399-409). The new chronology of Arslantepe IIIA.1 here proposed necessarily pushes back the final Late Bronze Age destruction, which was a uniform, widespread, and intense episode, to the first half of the 13th century BC. Indeed, material coming from the destruction level, although influenced, as said, by the Hittite imperial 
culture does not show any of those elements that have been recognized as typical of the 13th century BC at Hattuša (Schoop 2003; Manuelli 2013: 383-386). As a consequence, a high dating of the Late Bronze Age gateway destruction between the 14th and the beginning of the 13th century $\mathrm{BC}$ is plausible.

Material coming from both levels IIIA.1 and IIIA.2 at Arslantepe shows instead interesting changes. Indeed, next to the continuation of some aspects of the Hittite pottery production, the appearance of new forms, mostly found and spread in northern Syria has been stressed (Manuelli 2018). It is nonetheless essential to emphasize that in many Levantine sites these forms are already attested during the Late Bronze Age, as is shown for instance at Tell Afis (Venturi 2013), Alalakh (Montesanto and Pucci 2019) and Tell Kazel (Badre et al. 2018). The first spread of clay spools as well is nowadays set, with a certain margin of confidence, to the 13th century $\mathrm{BC}$, according to material from the Aegean and the Levantine regions (Mazar 2019: 121-122).

The dating of Arslantepe IIIA.1 to the mid-13th century BC shows that a new set of cultural influences as well as gradual disappearance of the central Anatolian material occurred at the site before the collapse of the Hittite empire took place. The historical implications related with these events will be the focus of future contributions. At the current state of the research, it can be assumed that the renowned political and cultural influence exerted by Karkemiš on Arslantepe at the beginning of the Iron Age has its origin already during the 13th century BC. The destruction of the Late Bronze Age gate system at Arslantepe can no longer be taken to represent the end of this era but, rather, it marks crucial changes in the history of the site that lead to new contacts and relationships.

To sum up, Arslantepe IIIA.1 represents an "intermediate" level that links two periods of the history of the site. Following the ${ }^{14} \mathrm{C}$ chronology, this is the last Late Bronze Age excavated level at Arslantepe. Nonetheless, culturally, this finds strict and solid connections with the following Iron Age levels. In this respect, it is also important to stress that the end of the Late Bronze age at Arslantepe is no longer to be seen as marked by a destruction, but rather by an abandonment. Indeed, the IIIA.1 structures are not damaged by fire and only a little material has been found in situ: the rooms have been probably used, cleaned up and abandoned within a period of maximum 136 years. Moreover, it also seems that the structures have been intentionally filled. The remains of the round tower, although sporadic, still represent further elements of continuity within the sequence, showing that the citadel was fortified during the whole advanced Late Bronze Age.

The fortification wall of Arslantepe IIIA. 2 represents thus the first proper Iron Age structure of the sequence. Its construction and use are now consistently dated between the late-13th and the late-11th century BC. The destruction of the fortification wall and the following IIIB levels, characterized by the presence of the plastered silos of the Iron Age II, fluctuate according to the ${ }^{14} \mathrm{C}$ chronology between the late 11 th and the 9 th century $\mathrm{BC}$. The previous archaeomagnetic date of the wall conflagration agrees well with this time interval despite its wide range. Pottery coming from the filling of the silos supports a low dating for the abandonment of these structures. Indeed, according to comparisons with sites from the northern Levant and the Middle Euphrates valley, the appearance of the well-known redslip ware and grooved ware pottery can hardly date the end of level IIIB before 900 BC (Pucci and Soldi 2019; Blaylock 2016: 14-20). This is anyhow confirmed by the lower 
chronological boundary of the sequence if we exclude the dating of charcoal from pit K1859. As stated above, the latter cuts stratigraphically the silos level.

\section{CONCLUSIONS}

This analysis provides important insights into the complexity of matching absolute chronologies with archaeological and historical sources. The results here proposed also bring new food for thought on the cultural dynamics that characterized the formation of the Iron Age kingdoms of the Syro-Anatolian region. The problem of dealing with the 12th century BC, combining material culture and historical data has been already well emphasized with specific focus on the Aegean world, especially in the absence of wide set of synchronized analyses and dating (Manning 2006-2007). As a matter of fact, the study and time setting of the agents that led to the collapse of the Late Bronze Age system and the subsequent regeneration of the independent Iron Age societies still need in-depth regional and local analyses and improvement in order to concretely pursue comprehensive reconstructions and synchronizations. Moreover, the assessment of regional variations in ${ }^{14} \mathrm{C}$ levels has to be taken into account (Manning et al. 2020). The offset episodes (growing season related) between the calibration datasets in the whole Mediterranean can change the calendar time ranges at high precision. Specifically, the time interval around the end of the Late Bronze Age and during the earlier Iron Age in the Aegean and Anatolian areas might be affected by up to several decades (Manning et al. 2018, 2020). In this respect, the revision here proposed of the 12th century BC levels at Arslantepe may be crucial to setting a high chronology and to synchronizing ${ }^{14} \mathrm{C}$ data with historical evidence.

\section{ACKNOWLEDGMENTS}

The present study was possible due to the research projects awarded by the Fritz Thyssen Stiftung (2014, project \# Az.20.13.0.200) and the Deutsche Forschungsgemeinschaft (20172020, project \#127370) conducted at the Freie Universität Berlin. The authors are deeply grateful to Marcella Frangipane, for her constant support and for having allowed the study of the material from Arslantepe presented here and to Laura Sadori, who leads the Laboratory of Palaeobotany and Palynology of Rome. Research carried out at Arslantepe has been made possible by the financial support of the Sapienza University of Rome and the Italian Ministry of Foreign Affairs. A special thanks is due to the National Geographic Society for the grant provided in 2016 to carry out research on the Iron Age levels. Finally, we are thankful to the anonymous reviewers for their excellent advice and suggestions for improvement. Federico Manuelli wrote the introduction and the discussion, Cristiano Vignola and Fabio Marzaioli the methods and the results; the three authors contributed together to write the conclusions. Isabella Passariello carried out the analyses at CIRCE lab, whose former director is Filippo Terrasi. Unless specified, images from Arslantepe belong to the project's archive (Missione Archeologica Italiana in Anatolia Orientale - CMAIAO).

\section{REFERENCES}

Alessio M, Bachechi F, Bella F, Cortesi C. 1966. University of Rome Carbon-14 Dates IV. Radiocarbon 8:401-412.

Alessio M, Bella F, Belluomini F, Calderoni G, Cortesi C, Improta S, Turi B. 1976. University of Rome Carbon-14 Dates XIV. Radiocarbon 18(3):321-349.

Alessio M, Bella F, Cortesi C. 1964. University of Rome Carbon-14 Dates II. Radiocarbon 6:77-90. 
Alessio M, Allegri L, Azzi C, Bella F, Calderoni G, Cortesi C, Improta S, Petrone V. $1983 .{ }^{14} \mathrm{C}$ dating of Arslantepe. Origini 12:575-580.

Badre L, Capet E, Vitale B. 2018. Tell Kazel au Bronze Récent. Études céramiques. Bibliothèque archéologique et Historique 211. Beirut: Institut Français Du Proche-Orient.

Blaylock S. 2016. Tille Höyük 3.2. The Iron Age: pottery, objects and conclusions. London: The British Institute of Archaeology.

Bronk Ramsey C. 2009a. Dealing with outliers and offsets in radiocarbon dating. Radiocarbon 51(3):1023-1045.

Bronk Ramsey C. 2009b. Bayesian analysis of radiocarbon dates. Radiocarbon 51(1):337-360.

Bronk Ramsey C, Lee S. 2013. Recent and planned developments of the program OxCal. Radiocarbon 55(2):720-730.

Bryce TR. 2012. The World of the Neo-Hittite Kingdoms: a political and military history. Oxford-New York: Oxford University Press.

Calcagnile L, Maruccio L, Scrimieri L, delle Side D, Braione E, D’Elia M, Quarta G. 2019. Development and Application of Facilities at the Centre for Applied Physics, Dating and Diagnostics (CEDAD) at the University of Salento during the Last 15 years. Nuclear Instruments and Methods in Physics Research, Section B: Beam Interactions with Materials and Atoms 456:252-256.

Calderoni G, Caneva I, Cazzella A, Frangipane M, Petrone V. 1994. Department of Earth Sciences at the University of Rome Radiocarbon Dates III. Radiocarbon 36(1):143-152.

Delaporte L. 1940. Malatya: fouilles de la mission archéologique française. Arslantepe, La Porte des Lions. Paris: De Boccard.

D'Elia M, Calcagnile L, Quarta G, Rizzo A, Sanapo C, Laudisa M, Toma U, Rizzo A. 2004. Sample preparation and blank values at the AMS radiocarbon facility of the University of Lecce. Nuclear Instruments and Methods in Physics Research Section B: Beam Interactions with Materials and Atoms 223-224:278-283.

De Martino S. 2018. The fall of the Hittite kingdom. Mesopotamia 53:23-47

Dinçol A, Dinçol B, Hawkins JD, Marchetti N, Peker A. 2014. A new Stele from Karkemish: at the origins of the Suhi-Katuwa dynasty. In: Marchetti N, editor. Karkemish: an ancient capital on the Euphrates. Bologna: Ante Quem. p. 127-131.

Di Nocera GM. 2000. Radiocarbon datings from Arslantepe and Norşuntepe: the fourth-third millennium absolute chronology in the Upper Euphrates and Transcaucasian region. In: Marro C, Hauptmann H, editors. Chronologies for the 4th-3rd millennium B.C. From the Euphrates to the Caucasus. Actes du Colloque d'Istanbul, 16-19 décembre 1998. IstanbulParis: De Boccard. p. 73-93.
Ertepinar P, Langereis CG, Biggin AJ, Frangipane M, Matney T, Ökse T, Engin A. 2012. Archaeomagnetic study of five mounds from Upper Mesopotamia between 2500 and 700 BCE: further evidence for an extremely strong geomagnetic field ca. 3000 years ago. Earth and Planetary Science Letters 357-358:84-98.

Frangipane M. 2019. Arslantepe. The rise and development of a political centre: from temple to palace to a fortified citadel. In: Durak N, Frangipane M, editors. 1st International Arslantepe Archaeology Symposium, 4-6 October 2018 Malatya. Malatya: Inönü Universitesi Matbaasi. p. 71-104.

Frangipane M, Liverani M. 2013. Neo-Hittite Melid: Continuity or Discontinuity? In: Yener A, editor. Across the border: Late Bronze-Iron Age relations between Syria and Anatolia. Proceedings of a Symposium held at the Research Center of Anatolian Studies, Koç University, Istanbul, May 31-June 1, 2010. Ancient Near Eastern Studies Supplement Series 42. Leuven-Paris-Walpole: Peeters. p. 349-371.

Frangipane M, Manuelli F, Vignola C. 2017. Arslantepe, Malatya: recent discoveries in the 2015 and 2016 seasons. In: Steadman SR, McMahon G, editors. The archaeology of Anatolia: recent discoveries. Volume II, 20152016. Cambridge: Cambridge Scholars Publishing. p. 66-92.

Frangipane M, Balossi Restelli F, Manuelli F, Mori L, Di Nocera GM, Erdal YS. 2019. Recent Late Chalcolithic and Iron Age discoveries at Arslantepe: the 2017-2018 campaigns. Steadman SR, McMahon G, editors. The archaeology of Anatolia: recent discoveries. Volume III, 2017-2018. Cambridge: Cambridge Scholars Publishing. p. 15-32.

Genz H, Mielke DP. 2011. Research on the Hittites: a short overview. In: Genz H, Mielke DP, editors. Insights into Hittite history and archaeology. Leuven-Paris-Walpole: Peeters. p. 1-30.

Griggs CB, Kuniholm PI, Newton MW, Watkins J, Manning SW. 2009. A 924-year regional oak tree-ring chronology for North-Central Turkey. In: Manning SW, Bruce MJ, editors. Tree-rings, kings, and Old World archaeology and environment. Oxford: Oxbow Books. p. 71-80.

Hawkins JD. 2000. Corpus of hieroglyphic Luwian inscriptions. Berlin: De Gruyter.

Hawkins JD, Weeden M. 2016. Sketch history of Karkemish in the earlier Iron Age (Iron I-IIB). In: Wilkinson TJ, Peltenburg E, Barbanes Wilkinson E, editors. Carchemish in context: the Land of Carchemish Project, 2006-2010. Oxford-Philadelphia: Oxbow Books. p. 9-12.

Kim J, Wright DK, Hwang J, Kim J, Oh Y. 2019. The old wood effect revisited: a comparison of radiocarbon dates of wood charcoal and shortlived taxa from Korea. Archaeological and Anthropological Sciences 11(7):3435-3448. 
Knapp AB, Manning SW. 2016. Crisis in Context: The end of the Late Bronze Age in the Eastern Mediterranean. American Journal of Archaeology 120(1):99-149.

Liverani M. 2012. Melid in the Early and Middle Iron Age: archaeology and history. In: Galil G, Gilboa A, Maeir AM, Kahn D, editors. The Ancient Near East in the 12th-10th centuries BCE. Culture and History. Münster: Ugarit Verlag. p. 327-344.

Manning SW. 2006-2007. Why radiocarbon dating 1200 BCE is difficult: a sidelight on dating the end of the Late Bronze Age and the contrarian contribution. Scripta Mediterranea 27-28:53-80.

Manning SW, Griggs C, Lorentzen B, Bronk Ramsey C, Chivall D, Jull AJT, Lange TE 2018. Fluctuating radiocarbon offsets observed in the southern Levant and implications for archaeological chronology debates. Proceedings of the National Academy of Sciences of the United States of America 115:6141-6146.

Manning SW, Kromer B, Cremaschi M, Dee MW, Friedrich R, Griggs C, Hadden CS. 2020. Mediterranean radiocarbon offsets and calendar dates for prehistory. Science Advances 6(12): eaaz1096.

Manuelli F (with the contributions by Bartosiewicz L, Bozzetti G, Bököny S, Buccolieri, A, Laurito R, Lemorini C, Mora C, Serra A, Siracusano G). 2013. Arslantepe IX - Late Bronze Age. Hittite Influence and Local traditions in an Eastern Anatolian Community. Rome: Sapienza Universitá di Roma.

Manuelli F. 2018. Drifting southward? Tracing aspects of cultural continuity and change in the late 2nd Millennium BC Syro-Anatolian region. Studia Eblaitica 4:139-186.

Manuelli F. 2019. From the Margin of the Hittite State to the Capital of the Kingdom of Medid: the Late Bronze Age and Iron Age developments at Arslantepe. In: Durak N, Frangipane $\mathrm{M}$, editors. 1st International Arslantepe Archaeology Symposium, 4-6 October 2018 Malatya. Malatya: Inönü Universitesi Matbaas1. p. 157-171.

Manuelli F. 2020. The Regeneration of the Late Bronze Age traditions and the formation of the kingdom of Malizi. In: Sonne A, editor. Formation, organization and development of the Iron Age societies. Vienna: Österreichischen Akademie der Wissenschaften. p. 109-129.

Manuelli F, Mori L. 2016. The king at the gate. Monumental fortifications and the rise of local elites at Arslantepe at the end of the 2nd Millennium BCE. Origini 39:203-235.

Marzaioli F, Borriello G, Passariello I, Lubritto C, de Cesare N, D’Onofrio A, Terrasi F. 2008. Zinc Reduction as an Alternative Method for AMS Radiocarbon Dating: Process Optimization at CIRCE. Radiocarbon 50(1):139-149.
Mazar A. 2019. Weaving in Iron Age Tel Rehov and the Jordan Valley. Journal of Eastern Mediterranean Archaeology and Heritage Studies 7(1):118-137.

Montesanto M, Pucci M. 2019. The Iron Age At Alalakh. In: Welton L, Haraf $\mathrm{H}$, editors. The Iron I in The Levant: the View from the North. Archaeology and History of Lebanon 50. London: Lebanese British Friends of the National Museump. p. 93-135.

Passariello I, Marzaioli F, Lubritto C, Rubino M, D'Onofrio A, de Cesare N, Borriello G, Casa G, Palmieri A, Rogalla D, Sabbarese C, Terrasi F. 2007. Radiocarbon sample preparation at the CIRCE AMS Laboratory in Caserta, Italy. Radiocarbon 49(2):225-232.

Pecorella PE. 1975. Malatya - III. Rapporto preliminare delle campagne 1963-1968. Il livello eteo imperiale e quelli neoetei. Rome: Centro per le antichità e la storia dell'arte del Vicino Oriente.

Pucci M, Soldi S. 2019. Going Red in the Iron Age II: The Emergence of Red-Slip Pottery in Northern Levant with Specific Reference to Tell afis, Chatal Höyük and Zincirli Höyük. In: Valentini S, Guarducci G, editors. Between Syria and the Highlands. Studies in Honor of Giorgio Buccellati and Marilyn Kelly-Buccellati. Studies on the Ancient Near East and the Mediterranean 3. Rome: Arbor Sapientiaep. p. 352-363.

Reimer PJ, Austin W, Bard E, Bayliss A, Blackwell P, Bronk Ramsey C, Butzin M, Cheng H, Edwards R, Friedrich M, Grootes $\mathrm{P}$, Guilderson $\mathrm{T}$ et al. 2020. The IntCal20 Northern Hemisphere radiocarbon age calibration curve $(0-55$ cal kBP). Radiocarbon 62.

Schachner A. 2020. The 14th and 13th Centuries BC in the Hittite Capital City Hattuša: a (re-) assessment. In: de Martino S, Devecchi E, editors. Anatolia Between the 13th and the 12th century BCE. Eothen 23. Florence: LoGisma. p. $381-410$.

Schoop UD. 2003. Pottery Traditions of the Late Hittite Empire: problems and definition. In: Fischer B, Genz H, Jean É, Köroğlu K, editors. Identifying changes. The transition from Bronze to Iron Age in Anatolia and its neighbouring regions. Proceedings of the International Workshop, Istanbul, November 8-9, 2002. Istanbul: Türk Eskiçağ Bilimleri Enstitüsüp. p. 167-178.

Schoop UD, Seeher J. 2006, Absolute Chronologie in Boğazköy-Hattuša: das Potential der Radiokarbondaten. In: Mielke DP, Schoop UD, Seeher J, editors. Strukturierung und Datierung in der hethitischen Archäologie. Voraussetzungen - Probleme - Neue Ansätze. Internationaler Workshop, Istanbul, 26-27 November 2004. BYZAS 4. Istanbul: Ege Yayinlari. p. 53-75. 
Seeher J. (with the controbutions by Schoop UD, Kühn S.). 2018. Buyukkaya II: Bauwerke und Befunde der Grabungskampagnen 1952-1955 und 1993-1998. Berlin-Boston: De Gruyter.

Stuiver M, Polach HA. 1977. Discussion: reporting of ${ }^{14} \mathrm{C}$ data. Radiocarbon 19:355-363.

Terrasi F, De Cesare N, D'Onofrio A, Lubritto C, Marzaioli F, Passariello I, Rogalla D, Sabbarese C, Borriello G, Casa G, Palmieri A. 2008. High precision ${ }^{14} \mathrm{C}$ AMS at CIRCE. Nuclear Instruments and Methods in Physics Research Section B: Beam Interactions with Materials and Atoms 266:2221-2224.

Venturi F. 2013. The Transition from the Late Bronze Age to the Early Iron Age at Tell Afis, Syria (phases VII-III). In: Yener A, editor. Across the border: Late Bronze-Iron Age relations between Syria and Anatolia. Proceedings of a Symposium held at the Research Center of Anatolian Studies, Koç University, Istanbul, May 31-June 1, 2010. Ancient Near Eastern Studies Supplement Series 42. Leuven-ParisWalpole: Peetersp. p. 227-259.

Vignola C, Marzaioli F, Balossi Restelli F, Di Nocera GM, Frangipane M, Masi A, Passariello I, Sadori L, Terrasi F. 2019. Changes in the Near Eastern Chronology between the 5th and the 3rd Millennium BC: new AMS ${ }^{14} \mathrm{C}$ dates from Arslantepe (Turkey). Nuclear Instruments and Methods in Physics Research Section B: Beam Interactions with Materials and Atoms 456:276-282. 